\title{
Some effects of feeding sheep on low-sodium hay with and without sodium supplement
}

\author{
By D. I. H. JONES AND D. G. MILES \\ Welsh Plant Breeding Station \\ AND K. B. SINCLAIR \\ Animal Health Research Unit, University College of Wales, Aberystwyth \\ (Received 8 September I966-Accepted I7 November I966)

\begin{abstract}
I. After a preliminary period on pelleted perennial ryegrass hay $(0.28 \%$ sodium in dry matter) groups of sheep were fed on timothy hay $(0.04 \% \mathrm{Na})$ with and without added sodium chloride or sodium bicarbonate.

2. When the sheep were fed on timothy hay, the $\mathrm{Na}$ content of urine and faeces fell and balances were negative. Na content of saliva fell markedly and potassium content increased.

3. Supplementary $\mathrm{Na}$ prevented these changes.

4. The low levels of dietary $\mathrm{Na}$ appeared to have no effect on the well-being of the sheep.
\end{abstract}

In the literature there is little information regarding the sodium requirement of sheep although some aspects of $\mathrm{Na}$ metabolism in ruminants have been studied. Brouwer (1961), for instance, has pointed out that the ruminant can conserve $\mathrm{Na}$ when the diet is deficient by reducing its excretion in urine and faeces. Changes have also been reported in the composition of saliva. Denton (1956) showed that Na deficiency induced by parotid cannulation of sheep resulted in a fall in $\mathrm{Na}$ and a rise in potassium concentration in the parotid saliva. Subsequently, Dobson, Kay \& McDonald (1960) showed that changes in the composition of parotid saliva were reflected in the composition of mixed saliva and, more recently, Dobson \& McDonald ( I $_{9} 6_{3}$ ) demonstrated similar changes in the mixed saliva of sheep grazing a pasture of low Na content.

The purpose of the experiment now presented was to examine the effect of $\mathrm{Na}$ supplementation in sheep fed on a low-Na diet. Groups of sheep were fed on timothy hay with or without added sodium chloride or sodium bicarbonate, and changes in the composition of saliva, blood, urine and faeces were studied. Timothy hay was chosen for this experiment because previous work by ap Griffith, Jones \& Walters (1965) showed that this species is invariably low in Na. Two different $\mathrm{Na}$ salts were used as supplements in order to establish that any changes which occurred were due to $\mathrm{Na}$ rather than the anion.

Butler ( 1963 ) reported an apparent relationship between pasture $\mathrm{Na}$ and the incidence of hypomagnesaemia in cattle, and Dobson, Scott \& McDonald (I966) have recently suggested that the raised aldosterone levels which occur in $\mathrm{Na}$ deficiency may be of some significance in hypomagnesaemia. The opportunity was taken during the present experiment to observe any changes in serum magnesium levels. 
EXPERIMENTAL

Animals and feeding. Nine mature Clun wethers, each weighing about $50 \mathrm{~kg}$, were placed at random in metabolism cages and fed on pelleted S.24 perennial ryegrass, containing $0.28 \% \mathrm{Na}$ in the dry matter, at the rate of $890 \mathrm{~g}$ dry matter/day in two feeds. After ro days the sheep were divided into three groups and fed as follows: group A received pelleted S. 5I timothy hay containing $0.04 \% \mathrm{Na}$, group B received the same pelleted hay, but with added sodium chloride to a level of $0 \cdot 28 \% \mathrm{Na}$, and group $\mathrm{C}$ received the same hay, but with added sodium bicarbonate to a level of $0.25 \% \mathrm{Na}$. The supplementary $\mathrm{Na}$ salts were introduced as solutions during the cubing process and the pellets were offered at a rate of $\mathrm{I} \mathrm{kg} /$ day in two feeds, each of $500 \mathrm{~g}$. This was equivalent to $840 \mathrm{~g}$ dry matter for group $\mathrm{A}, 870 \mathrm{~g}$ for group $\mathrm{B}$ and $850 \mathrm{~g}$ for group $\mathrm{C}$. These rations were given for a period of 28 days and the sheep had free access to deionized water. Samples of mixed saliva and jugular blood were obtained before the first feed on I day each week during the experiment. The saliva was collected from the base of the tongue by suction through a polythene tube inserted into the mouth.

Table I. Chemical composition of feeds ( $g / \mathrm{ro0} g$ dry matter)

$\begin{array}{lcc}\text { Constituent } & \begin{array}{c}\text { Perennial } \\ \text { ryegrass }\end{array} & \text { Timothy } \\ \text { Nitrogen } & 1.52 & 0.92 \\ \text { Sodium } & 0.28 & 0.04 \\ \text { Potassium } & 2.36 & 2.29 \\ \text { Magnesium } & 0.15 & 0.07 \\ \text { Phosphorus } & 0.21 & 0.18 \\ \text { Calcium } & 0.26 & 0.10\end{array}$

The intake of feed and output of faeces and urine were measured over 4 days during the preliminary period on perennial ryegrass hay and during two further 4-day periods

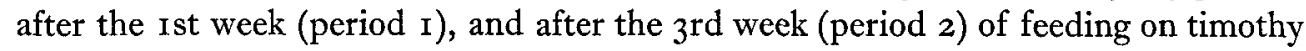
hay. In calculating the balance values, no allowance was made for cutaneous losses.

Analytical methods. Samples of the feed were dried in a force-draught oven, milled and stored until analysed. Faeces and urine samples were bulked for each collection period and stored at $-10^{\circ}$ until required for analysis. $\mathrm{Na}$ and other minerals were determined in feeds, faeces and urine after dry-ashing and acid extraction of the ash. Saliva and plasma were prepared for analysis by direct dilution with water. $\mathrm{Na}$ and $\mathrm{K}$ were determined by flame photometry and $\mathrm{Mg}$ by atomic absorption spectroscopy. The composition of the experimental feeds is shown in Table $\mathrm{r}$.

Analysis of variance was carried out for each sampling date or collection period and least significant differences between group means are given in the tables. Where mean values are quoted in the text they are accompanied by the standard error of the mean. 


\section{RESULTS}

Feed intake. During the preliminary period all the sheep readily consumed their full ration of cubed perennial ryegrass, giving a dry-matter intake of $890 \mathrm{~g} /$ day. Table 2 shows that the intake decreased when pelleted timothy hay was introduced and decreased further as the experiment progressed. There was some evidence of a higher intake in the group supplemented with sodium bicarbonate although the differences were not statistically significant. Towards the end of the experiment, all the sheep, and particularly those of group A, began to chew the wooden uprights supporting the feed containers.

Table 2. Mean dry-matter intake ( $g /$ day) of sheep fed on timothy hay with and without sodium supplement

$\begin{array}{cccc}\text { Group } & \text { Supplement } & \text { Period } \mathrm{x} & \text { Period } 2 \\ \text { A } & \text { None } & 776 & 729 \\ \text { B } & \text { Sodium chloride } & 791 & 739 \\ \text { C } & \text { Sodium bicarbonate } & 845 & 798 \\ \text { Least significant difference }(P=0 \cdot 05) & 120 & 105 \\ & (P=0.01) & 181 & 159\end{array}$

Table 3. Mean sodium and potassium concentration (m-equiv./l.) in saliva of sheep fed on timothy hay with and without sodium supplement

(Each figure represents the mean value for three sheep)

\begin{tabular}{|c|c|c|c|c|c|c|c|c|c|}
\hline \multirow[b]{2}{*}{ Group } & \multirow[b]{2}{*}{ Supplement } & \multicolumn{2}{|c|}{ Week I } & \multicolumn{2}{|c|}{ Week 2} & \multicolumn{2}{|c|}{ Week 3} & \multicolumn{2}{|c|}{ Week 4} \\
\hline & & $\mathrm{Na}$ & $\mathrm{K}$ & $\mathrm{Na}$ & $\mathrm{K}$ & $\mathrm{Na}$ & $\mathrm{K}$ & $\mathrm{Na}$ & $\mathbf{K}$ \\
\hline A & None & 122 & 27.4 & 117 & $32 \cdot 3$ & II9 & 33.5 & $\mathrm{ro} 3$ & $37 \cdot 1$ \\
\hline B & Sodium chloride & 156 & $12 \cdot 8$ & 147 & $14 \cdot 6$ & 160 & $14 \cdot 8$ & 147 & $12 \cdot 0$ \\
\hline $\mathrm{C}$ & Sodium bicarbonate & 143 & $17 \cdot 2$ & 140 & $12 \cdot 3$ & 160 & II 3 & 146 & I2.5 \\
\hline \multicolumn{10}{|c|}{ Least significant difference } \\
\hline$(P$ & $.05)$ & II 3 & $\begin{array}{r}6.9 \\
\end{array}$ & $\begin{array}{r}143 \\
2.8\end{array}$ & 10.2 & 17.0 & 12.3 & 28.7 & 10.1 \\
\hline
\end{tabular}

Digestibility. The mean dry-matter digestibility was $47 \cdot 3 \pm 2 \cdot 1 \%$ for perennial ryegrass and $50 \cdot 0 \pm 0.8 \%$ for timothy. Supplementation with either sodium chloride or sodium bicarbonate did not affect the digestibility of timothy hay.

Saliva. The weekly samples of mixed saliva showed mean values for the preliminary period of $172.5 \pm 18.6 \mathrm{~m}$-equiv. $\mathrm{Na}^{+} / \mathrm{l}$. and $\mathrm{I} 6.8 \pm 8.2 \mathrm{~m}$-equiv. $\mathrm{K}^{+} / 1$. Table 3 shows the mean saliva $\mathrm{Na}$ and $\mathrm{K}$ content for each of the 4 weeks of the experimental period during which the sheep were fed on timothy hay.

After I week on timothy there was a fall in the $\mathrm{Na}$ content of the saliva of all the sheep. This was particularly marked in group $A$ and the mean level was significantly lower than the mean for either group B or $\mathrm{C}$. There was a coincident rise in the $\mathrm{K}$ content of the saliva in group A to a level significantly higher than in either group $B$ or $C$. These changes progressed until, at the end of the experiment, the Na:K ratio for group A was $2 \cdot 8$, for group $\mathrm{B} 12 \cdot 3$, and for group $\mathrm{C}+1 \cdot 7$. 
Urine. Following the change of feed to timothy there was an unexplained increase in the mean volume of urine produced per sheep from $423 \pm 64$ to $965 \pm 385 \mathrm{ml} /$ day. Unfortunately this change cannot be related to water intake since the latter was not measured. There were no significant differences in volume between the groups.

The mean levels of urine $\mathrm{Na}$ and $\mathrm{K}$ found during the preliminary period on perennial ryegrass were $\mathrm{I}_{3} \cdot 9 \pm 6 \cdot 0 \mathrm{~m}$-equiv. $\mathrm{Na}^{+} / 1$. and $678 \pm 105 \mathrm{~m}$-equiv. $\mathrm{K}+/ 1$. Table 4 shows the mean contents of $\mathrm{Na}$ and $\mathrm{K}$ during the two collection periods when timothy was given. The introduction of the timothy was followed by a rise in urine $\mathrm{Na}$ content in groups B and C, but a marked fall in group A to a level significantly less than that of either group $B$ or $C$. The urine $\mathrm{K}$ content decreased in all sheep when the feed was changed to timothy, but the differences between the groups were not significant.

\section{Table 4. Mean concentration and the amount of sodium and potassium excreted} in the urine of sheep fed on timothy hay with and without sodium supplement

(Each figure represents the mean value for three sheep)

\begin{tabular}{|c|c|c|c|c|c|c|c|c|c|}
\hline \multirow[b]{3}{*}{ Group } & \multirow[b]{3}{*}{ Supplement } & \multicolumn{4}{|c|}{ Concentration (m-equiv./l.) } & \multicolumn{4}{|c|}{ Amount (g/4 days) } \\
\hline & & \multicolumn{2}{|c|}{ Period I } & \multicolumn{2}{|c|}{ Period 2} & \multicolumn{2}{|c|}{ Period I } & \multicolumn{2}{|c|}{ Period 2} \\
\hline & & $\mathrm{Na}$ & $\mathrm{K}$ & $\mathrm{Na}$ & $\mathbf{K}$ & $\mathrm{Na}$ & $\mathrm{K}$ & $\mathrm{Na}$ & K \\
\hline $\mathrm{A}$ & None & $4 \cdot 0$ & 468 & $2 \cdot 61$ & $3 \times 2$ & $0 \cdot 207$ & $40 \cdot 4$ & 0.230 & $42 \cdot 9$ \\
\hline $\mathrm{B}$ & Sodium chloride & $33 \cdot 5$ & 253 & $3 I \cdot 5$ & 276 & 3.997 & $48 \cdot 9$ & 3.020 & 50.5 \\
\hline $\mathrm{C}$ & Sodium bicarbonate & $36 \cdot 0$ & 433 & $39 \cdot 2$ & 456 & $2 \cdot 587$ & $52 \cdot 5$ & $2 \cdot 483$ & $47 \cdot 8$ \\
\hline \multicolumn{10}{|c|}{ Least significant difference } \\
\hline$(P=$ & $=0.05)$ & $27 \cdot 4$ & 247 & $22 \cdot 8$ & I 88 & 0.287 & $16 \cdot 6$ & 0.993 & $26 \cdot 3$ \\
\hline$(P=$ & $=0.01)$ & $4 \mathrm{I} \cdot 5$ & 375 & $34 \cdot 5$ & 284 & 0.435 & $25 \cdot 3$ & $I \cdot 505$ & $39 \cdot 9$ \\
\hline
\end{tabular}

The amount excreted per sheep during the 4-day collection period in which perennial ryegrass was given was $0.535 \pm 0.242 \mathrm{~g}$ for $\mathrm{Na}$ and $44 \cdot 2 \pm 6.3 \mathrm{~g}$ for $\mathrm{K}$. When the feed was changed to timothy the amount of $\mathrm{Na}$ excreted in the urine fell in group $\mathrm{A}$, but increased in groups $\mathrm{B}$ and $\mathrm{C}$ : the latter change was due to a rise in both $\mathrm{Na}$ content and urine output. There was little change in the amount of $\mathrm{K}$ excreted in the urine following the change of feed. Table 4 shows a highly significant difference in the amount of $\mathrm{Na}$ but no significant difference in the amount of $\mathrm{K}$ excreted in the three groups.

The $\mathrm{Mg}$ level in urine when perennial ryegrass was given was $37^{\circ} 0 \pm 9 \cdot 7 \mathrm{~m}$-equiv./1. Following the introduction of timothy hay, urine $\mathrm{Mg}$ fell in all groups to a mean of $8 \cdot 22 \pm 5.0 \mathrm{~m}$-equiv./1. There was no evidence that the $\mathrm{Na}$ supplement had any effect on the $\mathrm{Mg}$ content of urine.

Faeces. During the preliminary period on perennial ryegrass, the mean level of Na in the faeces was $0 \cdot 40 \pm 0.05 \%$ and of $\mathrm{K}_{1} \cdot 72 \pm 0.28 \%$. After changing the feed to timothy there was a fall in the $\mathrm{Na}$ content of the faeces of all sheep, but it was particularly marked in group A. Table 5 shows that the level of faecal $\mathrm{Na}$ was significantly lower in group A than in either group B or C. The table also shows that group $\mathrm{A}$ excreted significantly less $\mathrm{Na}$ and significantly more $\mathrm{K}$ in the faeces than group $\mathrm{B}$ or $\mathrm{C}$. 
The Mg content of the faeces fell from a mean level of $0.21 \pm 0.01 \%$ during the preliminary period to $0.1 I \pm 0.01 \%$ after the introduction of timothy hay. Differences between groups were not significant, indicating that $\mathrm{Na}$ supplementation did not affect the excretion of $\mathrm{Mg}$ in the faeces.

Retention of $N a$ and $K$. Although there was considerable variation between individual animals, $\mathrm{Na}$ and $\mathrm{K}$ balances were positive in all the sheep during the preliminary period on perennial ryegrass. The amount of $\mathrm{Na}$ retained during the 4 -day collection period was $0.66 \mathrm{~g}(0.42-3.40 \mathrm{~g})$ per sheep and of $\mathrm{K} 7 \cdot 7 \mathrm{~g}(\mathrm{I} \cdot 7-\mathrm{Ir} \cdot 3 \mathrm{~g})$ per sheep.

Table 6 shows that following the introduction of timothy hay the $\mathrm{Na}$ balances remained positive for groups $\mathrm{B}$ and $\mathrm{C}$, but became negative for group $\mathrm{A}$; the differences between group means were statistically significant. It is interesting to note that the retention of $\mathrm{Na}$ was higher during period 2 in all groups. The change of diet led to erratic $\mathrm{K}$ balances and no significant differences were apparent.

Table 5. Mean concentration and amount of sodium and potassium excreted in the faeces of sheep fed on timothy hay with and without sodium supplement

(Each figure represents the mean value for three sheep)

\begin{tabular}{|c|c|c|c|c|c|c|c|c|c|}
\hline \multirow[b]{3}{*}{ Group } & \multirow[b]{3}{*}{ Supplement } & \multicolumn{4}{|c|}{ Concentration ( $g / 100 \mathrm{~g}$ dry faeces) } & \multicolumn{4}{|c|}{ Amount ( $\mathrm{g} / 4$ days) } \\
\hline & & \multicolumn{2}{|c|}{ Period I } & \multicolumn{2}{|c|}{ Period 2} & \multicolumn{2}{|c|}{ Period I } & \multicolumn{2}{|c|}{ Period 2} \\
\hline & & $\mathrm{Na}$ & $\mathrm{K}$ & $\mathrm{Na}$ & $\mathbf{K}$ & $\mathrm{Na}$ & $\mathbf{K}$ & $\mathrm{Na}$ & K \\
\hline A & None & 0.13 & $r \cdot 84$ & 0.07 & $I \cdot 85$ & $2 \cdot 07$ & $29 \cdot 90$ & $1 \cdot 02$ & $26 \cdot 23$ \\
\hline B & Sodium chloride & 0.24 & $1 \cdot 29$ & 0.17 & $I \cdot 25$ & $3 \cdot 77$ & 20.26 & $2 \cdot 53$ & $18 \cdot 14$ \\
\hline $\mathrm{C}$ & Sodium bicarbonate & 0.22 & $I \cdot 12$ & 0.15 & $I \cdot 1$ & 370 & 18.65 & $2 \cdot 37$ & 18.06 \\
\hline $\begin{array}{l}\text { Least } \mathrm{s} \\
\quad(P \\
(P\end{array}$ & $\begin{array}{l}\text { ignificant difference } \\
=0.05) \\
=0.01)\end{array}$ & $\begin{array}{l}0.06 \\
0.09\end{array}$ & $\begin{array}{l}0.39 \\
0.59\end{array}$ & $\begin{array}{l}0.06 \\
0.09\end{array}$ & $\begin{array}{l}0.30 \\
0.46\end{array}$ & $\begin{array}{l}I \cdot I 7 \\
I \cdot 78\end{array}$ & $\begin{array}{l}2 \cdot 19 \\
3 \cdot 33\end{array}$ & $\begin{array}{l}0.31 \\
0.46\end{array}$ & $\begin{array}{l}2.20 \\
3.40\end{array}$ \\
\hline
\end{tabular}

Table 6. Sodium balances of sheep fed on timothy hay with and without sodium supplement

(g sodium retained/4 days; each figure represents the mean value for three sheep)

\begin{tabular}{|c|c|c|c|}
\hline Group & Supplement & Period I & Period 2 \\
\hline A & None & $-I \cdot 12$ & 0.0 \\
\hline $\mathrm{B}$ & Sodium chloride & $\mathrm{I} \cdot 09$ & $2 \cdot 72$ \\
\hline $\mathrm{C}$ & Sodium bicarbonate & $2 \cdot 16$ & $3 \cdot 17$ \\
\hline \multicolumn{2}{|c|}{$\begin{array}{r}\text { Least significant difference }(P=0.05) \\
(P=0.0 \mathrm{I})\end{array}$} & $\begin{array}{l}I \cdot 25 \\
r \cdot 89\end{array}$ & $\begin{array}{l}\mathbf{1} \cdot 09 \\
\mathbf{1} \cdot 63\end{array}$ \\
\hline
\end{tabular}

Plasma. When perennial ryegrass was given, the mean level of plasma $\mathrm{Na}$ was I $39.9 \pm 2.27$ m-equiv./1., and of K $5.27 \pm 0.5^{8}$ m-equiv./1. After the change to timothy there was a marked fall in $\mathrm{Na}$ content to $123.0 \pm \mathrm{I} \cdot 18 \mathrm{~m}$-equiv./1., and a slight fall in $\mathrm{K}$ content to $4^{\circ} 93 \pm 0.5 \mathrm{I}$ m-equiv. $/ 1$. This level of plasma $\mathrm{Na}$ is unusually low and cannot be attributed to differences in $\mathrm{Na}$ intake since supplementation had no significant effect. It is difficult to account for this low result, but analytical error is unlikely as standard 
serums gave normal values. Plasma $\mathrm{Mg}$ fell from a level of $\mathrm{I} \cdot 46 \pm 0 \cdot \mathrm{I} 2 \mathrm{~m}$-equiv./1. on perennial ryegrass to $\mathrm{I}^{\prime} \mathbf{3 2} \pm 0.14 \mathrm{~m}$-equiv./l. on timothy. Group differences were not significant and it is apparent that $\mathrm{Na}$ supplementation did not affect $\mathrm{Na}, \mathrm{K}$ or $\mathrm{Mg}$.

\section{DISCUSSION}

In a recent report of the Agricultural Research Council (1965) the Na requirement of a $50 \mathrm{~kg}$ sheep was estimated to be $0.99-\mathrm{I} \cdot 4 \mathrm{I} \mathrm{g} /$ day, depending on the rate of growth. This is equivalent to $0.10-0.15 \% \mathrm{Na}$ in the dry feed at the level of intake in our experiment. The unsupplemented timothy hay $(0.04 \% \mathrm{Na})$ would therefore not be expected to provide an adequate amount of $\mathrm{Na}$. On the other hand, the supplemented timothy $(0.25-0.28 \% \mathrm{Na})$ would be expected to be adequate.

It is apparent from our results that $0.04 \% \mathrm{Na}$ in the diet was insufficient to prevent marked changes in saliva composition. Bott, Denton, Goding \& Sabine (1964) state that the normal Na content of ruminant parotid saliva is $160-175 \mathrm{~m}$-equiv./1., and the $\mathrm{K}$ content 4-6 m-equiv./1. In our experiment the mean levels of $172 \cdot 5 \mathrm{~m}$-equiv. $\mathrm{Na}^{+} / 1$. and $\mathrm{I} 6.9 \mathrm{~m}$-equiv. $\mathrm{K}^{+} / 1$. were found in mixed saliva during the preliminary period on perennial ryegrass. By the last week of the experimental period on unsupplemented timothy hay these values had changed to $103 \mathrm{~m}$-equiv. $\mathrm{Na}^{+} / 1$. and $37^{\cdot} \mathrm{I}$ m-equiv. $\mathrm{K}^{+} / 1$. Supplementation of timothy prevented this change, sodium chloride and sodium bicarbonate being equally efficient.

The dietary level of $0.04 \% \mathrm{Na}$ was also insufficient to maintain the sheep in positive $\mathrm{Na}$ balance despite the marked economy in excretion indicated by reduced levels in urine and faeces. The provision of supplementary $\mathrm{Na}$ prevented the occurrence of negative balances. It is interesting to note, however, that, although the intake of $\mathrm{Na}$ in groups $B$ and $C$ was maintained at a similar level during both preliminary and experimental periods, more appeared in the urine and less in the faeces during the experimental period when $\mathrm{Na}$ was given as a supplement. This indicates a difference in the utilization of the two forms of dietary $\mathrm{Na}$.

The change of feed from perennial ryegrass to timothy was followed by a fall in the level of plasma $\mathrm{Na}$ in both supplemented and unsupplemented groups and was due to factors other than the reduced intake of $\mathrm{Na}$.

Despite the changes observed in the saliva composition and $\mathrm{Na}$ balance, there appeared to be no adverse effect on the well-being of the sheep. A prolonged period of observation, however, may reveal a deleterious effect and this possibility is now under investigation. It is interesting that Briggs, Franklin \& McClymont (1957) found $\mathrm{Na}$ supplementation of a high-grain ration to improve the live-weight gain of fattening wethers, while McClymont, Wynne, Briggs \& Franklin (1957) found that Na supplementation of a similar ration given at maintenance level to dry ewes had no beneficial effect. More recently, Kemp \& Geurink (1966) have reported an increase in milk yield when cows were given a sodium chloride supplement after a period of 5 months on a low-Na diet.

The results of the present experiment do not show any relationship between the level of $\mathrm{Na}$ intake and the level of plasma $\mathrm{Mg}$. Thus, although the levels of plasma 
and urine $\mathrm{Mg}$ fell following the introduction of the timothy feed, supplementation with $\mathrm{Na}$ had no effect. It appears, therefore, that the fall reflected the lower Mg content of timothy.

\section{REFERENCES}

Agricultural Research Council (1965). The Nutrient Requirements of Farm Livestock. No. 2. Ruminants, p. 8I. London: Agricultural Research Council.

ap Griffith, G., Jones, D. I. H. \& Walters, R. J. K. (1965). F. Sci. Fd Agric. 16, 94.

Bott, E., Denton, D. A., Goding, J. R. \& Sabine, J. R. (1964). Nature, Lond. 202, 461.

Briggs, P. K., Franklin, M. C. \& McClymont, G. L. (1957). Aust. F. agric. Res. 8, 75.

Brouwer, E. (196I). In Digestive Physiology and Nutrition of the Ruminant, p. I 54. [D. Lewis, editor.] London: Butterworth.

Butler, E. J. (1963). F. agric. Sci., Camb. 60, 329.

Denton, D. A. (1956). F. Physiol., Lond. x3x, 516.

Dobson, A., Kay, R. N. B. \& McDonald, I. (1960). Res. vet. Sci. 1, 103.

Dobson, A. \& McDonald, I. (1963). Res. vet. Sci. 4, 247.

Dobson, A., Scott, D. \& McDonald, I. (1966). Res. vet. Sci. 7, 94.

Kemp, A. \& Geurink, J. H. (1966). Tijdschr. Diergeneesk. 91, 580.

McClymont, G. L., Wynne, K. N., Briggs, P. K. \& Franklin, M. C. (1957). Aust. F. agric. Res. 8, 83. 